$\overline{\text { Original }}$

\title{
Purification and Characterization of a New Anti-Nucleating Protein Isolated from Acinetobacter calcoaceticus KINI-1
}

\author{
HIDEHISA KAWAHARA*, ISAO NAGAE, AND HITOSHI OBATA \\ Department of Biotechnology, Faculty of Engineering, Kansai University \\ 3-3-35, Yamate-cho, Suita-city, Osaka 564, Japan
}

Received 27 April 1996/Accepted 7 June 1996

\begin{abstract}
Strain KINI-1 capable of producing an anti-nucleating agent was isolated from a camphor leaf. Strain KINI-1 was identified as Acinetobacter calcoaceticus from its characteristics and taxonomics; the optimum temperature and $\mathrm{pH}$ for the production of the anti-nucleating agent were $30^{\circ} \mathrm{C}$ and 7.0 , respectively. As the activity of this agent disappeared with the application of protease treatment, this agent, which was an anti-nucleating protein (ANP) was partially purified from the culture to an electrophoretically main band state by ultrafiltration, acetone precipitate, QA-52 column chromatography and Toyopearl HW 55S and Superose 12 gel filtration chromatography. The molecular weight of the ANP estimated by sodium dodecylsulfatepolyacrylamide gel electrophoresis was $55 \mathrm{kDa}$. The ANP had various substrate specificities for ice nuclei from various ice-nucleating bacteria and Agl. It was demonstrated that the antinucleating activity of ANP increased in proportion to the protein concentration and the antinucleating activity of ANP against ice nucleus from the cells of Erwinia uredovora KUIN-3 was $2.2^{\circ} \mathrm{C}$ at a concentration of $12.5 \mu \mathrm{g} / \mathrm{ml}$. Furthermore, we found that this ANP was bound to the surface of the ice nuclei, thereby causing anti-nucleating activity. The surface hydrophobicities of the ice nuclei were increased after binding with ANP, whereas the surface charge was changed from 6.6 to 6.1. Also, we confirmed that this action by ANP could give rise to a supercooling point at $-5.0^{\circ} \mathrm{C}$ in the cell suspension of Erwinia uredovora KUIN-3.
\end{abstract}

Key words : Ice-nucleating activity/Anti-nucleating activity/Acinetobacter sp.

\section{INTRODUCTION}

Some bacterial strains belonging to the genera Pseudomonas (Maki et al., 1974; Obata et al., 1987 and 1989), Xanthomonas (Kin et al., 1987) and Erwinia (Lindow et al., 1983 ; Obata et al., 1990) act as strong ice nuclei and promote the freezing of supercooled water efficiently. The ice crystals formed by these bacteria propagate into the plant tissues of cold-sensitive crops including tea plants, mulberry trees, fruit trees and vegetables, and their cells are injured by these ice crystals. Several chemical or physical methods for preventing frost injury are available (Ozawa, 1977). These methods, however, have limitations regarding effectiveness, materials costs and

*Corresponding author. Tel: +81-6-368-0832, Fax : +816-388-8609. labor expense. Although the use of fans has long been the most common means of preventing frost in tea fields, it sometimes even promotes frost injury when the atmospheric temperature happens to fall to $-3.0^{\circ} \mathrm{C}$ in spring (Ozawa, 1977). Anti-nucleating agents, which act against ice-nucleating bacteria, including antagonists (Lindow et al., 1983), antibiotic agents (Yakofsky et al., 1981), heavy metals and alkylbenzyldimethylammonium salts (Watanabe et al., 1988), have also been reported. Further, we have suggested that the smoke condensate of chaff and related substances, such as pyrocatechol and o-cresol, may be useful as antinucleating agents (Obata et al., 1987). We have also reported that triose reductone formed by glucose-alkaline degradation and a copper ion system could inactivate the ice-nucleating activity (Obata et al., 1992). These agents, which are chemicals, may be harmful to the ecology. Moreover, in 
view of safety we found that eugenol was an antinucleating agent from a spice which inhibits the icenucleating activity of Erwinia uredovora KUIN-3 (Kawahara et al., 1996). As biotechnological approaches, the discovery of natural Ina- phenotypes and success in the engineering of Ina $^{-}$mutations have made it possible to examine these Ina ${ }^{-}$phenotypes as a means to control Ina ${ }^{+}$populations and thus to reduce frost damage in agriculture (Lindow, 1988). Several field tests have been carried out and many more are under way (Wilson and Lindow, 1994), but the contamination of the environment by these bacteria might cause the disruption of other ecosystems in the field.

So far the substances having the anti-nucleating activity, which was similar to the activity of that of an anti-freezing protein (Choy and Daniel, 1992), produced by bacteria have been poorly studied. The present study was performed in an effort to isolate a bacterial strain capable of producing substances that inhibit the ice-nucleating activity of Erwinia uredovora KUIN-3. The ANP was purified by various column chromatographies, and we elucidated the antinucleating mechanism of this protein.

\section{MATERIALS AND METHODS}

\section{Isolation of a bacterium capable of producing an anti-nucleating agent}

Trypticase soy agar medium, which contained 1.2\% Trypticase soy broth (BBL Microbiology System, Cockeysville, MD.) and 1.5\% agar ( $\mathrm{pH} 7.0)$, was used for the first screening. The medium was autoclaved at $120^{\circ} \mathrm{C}$ for $20 \mathrm{~min}$. Leaf samples were placed on the agar plate and then incubated at $18^{\circ} \mathrm{C}$ until colonies appeared. Colonies which appeared were picked up, then inoculated into $10 \mathrm{ml}$ of the same medium and incubated at $18^{\circ} \mathrm{C}$ for $48 \mathrm{~h}$ with shaking. Cells in the culture were removed by centrifugation at $8,000 \times g$ for $15 \mathrm{~min}$, and the anti-nucleating activities of the resultant supernatants were examined. The screening was done in the same way until single bacterial colonies were obtained.

\section{Measurements of the ice-nucleating activity and anti-nucleating activity}

The ice-nucleating activity was measured using the method described by Vali (Vali, 1971). The icenucleating temperatures required to freeze 10\% $\left(T_{10}\right)$, $50 \%\left(T_{50}\right)$, and $90 \%\left(T_{90}\right)$ of the drops were measured. The ice-nucleating spectrum of the cell suspension was obtained by the droplet-freezing method as modified by Lindow et al. (Lindow et al., 1982). The freezing difference spectra in $\mathrm{D}_{2} \mathrm{O}$ versus $\mathrm{H}_{2} \mathrm{O}$ were measured using the method described by Turner et al. (Turner et al., 1990). Anti-nucleating activity was determined by using a suspension of lyophilized cell from Erwinia uredovora KUIN-3, which adjusted to an absorbance at $660 \mathrm{~nm}$ at 0.1 with $50 \mathrm{mM}$ potassium phosphate buffer $(\mathrm{pH} \mathrm{7.0)}$. After the culture broths were heated at $100^{\circ} \mathrm{C}$ for $10 \mathrm{~min}$, the anti-nucleating activity was determined as the follows; the samples $(0.45 \mathrm{ml})$ and the above cell suspension $(0.05 \mathrm{ml})$ were mixed and incubated at $18^{\circ} \mathrm{C}$ for $10 \mathrm{~min}$. The icenucleating activities of the mixture solutions were measured. The ice-nucleating activity of the mixture solution including $0.45 \mathrm{ml}$ of $50 \mathrm{mM}$ potassium phosphate buffer ( $\mathrm{pH}$ 7.0) was measured as a control, and then the activity was lowered by adding a sample which was regarded as having anti-nucleating activity.

\section{Culture conditions}

The effects of $\mathrm{pH}$ and temperature on the growth and anti-nucleating activity were examined using TS medium. Growth of the cell was monitored by following the optical density (OD) at $660 \mathrm{~nm}$. Cells were grown in $100 \mathrm{ml}$ of this medium in shaking flasks (500 $\mathrm{ml}$ ) at $18^{\circ} \mathrm{C}$. The large cultures (3.0 liters) using a jar fermenter for production of ANP were grown at $30^{\circ} \mathrm{C}$ for $16 \mathrm{~h}$.

\section{Purification of anti-nucleating protein from the culture broth of strain KINI-1}

After $16 \mathrm{~h}$ of incubation at $30^{\circ} \mathrm{C}$ with TS medium, the culture was centrifuged at $5,000 \times g$ for $30 \mathrm{~min}$ at $4^{\circ} \mathrm{C}$ to remove the bacteria. The supernatant (6 liter) was concentrated by ultrafiltration through a Minitan Ultrafiltration Filter Plate (nominal molecular weight cutoff of 10,000 , polysulfons, blue; Millipore Co.) to a volume of about $300 \mathrm{ml}$. The concentrated filtrate was added to 2 volumes of cold acetone, and this mixture was stirred at $4^{\circ} \mathrm{C}$ for $15 \mathrm{~min}$. After centrifugation at $5,000 \times g$ for $10 \mathrm{~min}$, the resultant precipitate was suspended in $50 \mathrm{mM}$ potassium phosphate buffer $(\mathrm{pH}$ 7.0) and exhaustively dialyzed against the same buffer to remove acetone. The dialysate solution ( $1 \mathrm{li}$ ter) was concentrated using polyethylene glycol 6000 and resuspended in $30 \mathrm{ml}$ of the same buffer. This suspension was loaded onto a QA 52-cellulose column (2.6 by $15 \mathrm{~cm}$ ) previously equilibrated with 50 $\mathrm{mM}$ potassium phosphate buffer $(\mathrm{pH} 7.0)$. This adsorbed protein was eluted by a linear gradient of $\mathrm{NaCl}$ from 0 to $1 \mathrm{M}$ in $120 \mathrm{ml}$ each of the same buffer.

Fractions of $6 \mathrm{ml}$ were collected and the active fractions (No. 7, 8, 9) eluted with $50 \mathrm{mM}$ potassium phosphate buffer ( $\mathrm{pH}$ 7.0) were pooled. After being concentrated, this sample was loaded on a column (1.6 by $80 \mathrm{~cm}$ ) of Toyopearl HW-55S equilibrated 
with $10 \mathrm{mM}$ potassium phosphate buffer $(\mathrm{pH} 7.0$ ) containing $0.15 \mathrm{M} \mathrm{NaCl}$ and was eluted with the same buffer. The active fractions were pooled, dialyzed and concentrated to a volume of $3 \mathrm{ml}$. This sample was then loaded on a Superose 12 ( 1 by $30 \mathrm{~cm}$ ) equilibrated with $10 \mathrm{mM}$ potassium phosphate buffer $(\mathrm{pH}$ 7.0) containing $0.15 \mathrm{M} \mathrm{NaCl}$ and was eluted with the same buffer. The active fractions were pooled and dialyzed against $10 \mathrm{mM}$ potassium phosphate buffer ( $\mathrm{pH}$ 7.0). This dialyzed solution was used as the final preparation of the anti-nucleating protein.

\section{SDS-polyacrylamide gel electrophoresis (PAGE)}

SDS-PAGE was done by the method of Laemmli (Laemmli, 1970) on $12.5 \%$ acrylamide gel in $0.1 \mathrm{M}$ Tris-glycine buffer using a slab apparatus. Proteins on the gel were stained by the silver staining method.

\section{Measurement of the charge on the surface of the cells}

The charge on the surface of the cells was measured using a fluorescence reagent as described in our paper (Kawahara et al., 1994). $0.1 \mathrm{ml}$ of cell suspension (OD, 0.1 ) was mixed with $0.9 \mathrm{ml}$ of ANP solution $(14.9 \mu \mathrm{g} / \mathrm{ml})$ with distilled water $(0.9 \mathrm{ml})$ as a control. These solutions were added to $30 \mu \mathrm{l}$ of 5 ( $\mathrm{N}$-hexadecanoyl)-amino-fluorescein ethanol solution $\left(10^{-4} \mathrm{M}\right)$ and then incubated at $18^{\circ} \mathrm{C}$ for $30 \mathrm{~min}$ in darkness. The ratio of fluorescent intensity at an emission of $530 \mathrm{~nm}$ to $495 \mathrm{~nm}$ was measured using a fluorospectrometer (Hitachi F4010) at $495 \mathrm{~nm}$.

\section{Measurement of freezing curve}

$10 \mathrm{ml}$ of cell suspension (OD, 0.1) from Erwinia uredovora KUIN-3 in the presence or absence of ANP $(1.49 \mu \mathrm{g} / \mathrm{ml})$ was placed into silicone-coated Pyrex glasses $(18 \times 130 \mathrm{~mm})$ and then cooled in a methanol bath at $-10^{\circ} \mathrm{C}$ with a Program culture freezer MPF1000 (EYELA Co.). A temperature sensor was inserted into the sample and changes in the sample temperatures were measured for each $30 \mathrm{~s}$ period.

\section{Assays}

The amount of reducing saccharide was monitored by the absorbance at $492 \mathrm{~nm}$ using the phenolsulfuric acid method. Protein was measured by the method of Lowry et al. (Lowry et al., 1951) with bovine serum albumin as the standard.

\section{Chemicals}

Molecular weight markers used for SDS-PAGE and gel filtration were obtained from Pharmacia LKB Biotechnology. The QA 52 carrier used for anion exchange column chromatography was obtained from Whatman Co., Ltd. The Toyopearl HW 55S carrier used for gel filtration column chromatography was obtained from Tosoh Co., Ltd. All other chemicals used were of analytical grade and were obtained from Wako Pure Chemical Industries, Ltd. (Osaka).

\section{RESULTS AND DISCUSSION}

\section{Isolation of a bacterium capable of producing an anti-nucleating agent}

The bacteria found on the surfaces of various plant leaves were isolated on the basis of colony colors and (a)

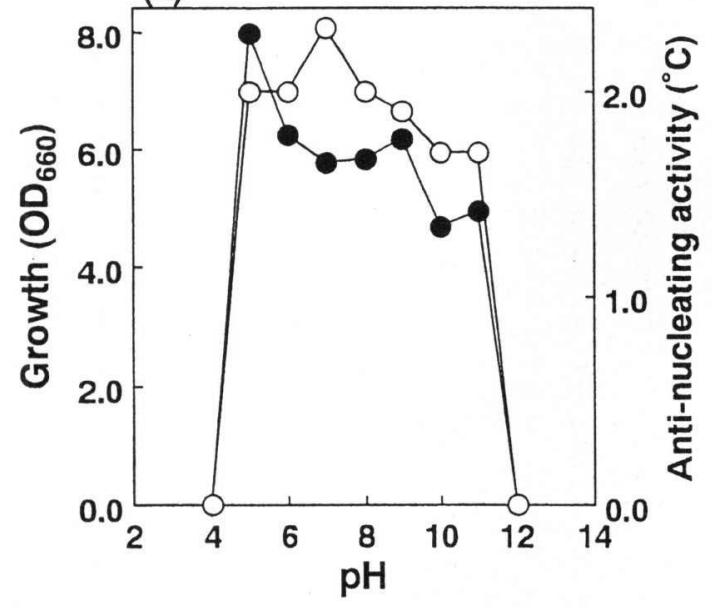

(b)

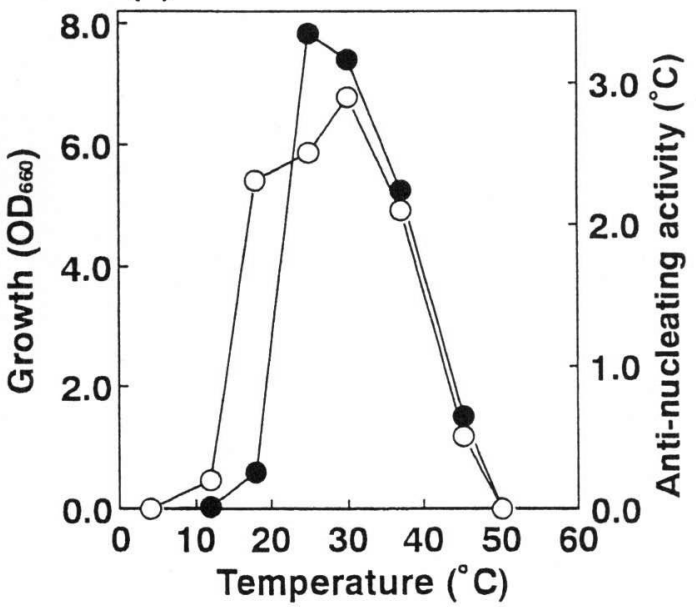

FIG. 1. Effects of pH (a) and temperature (b) on the growth and anti-nucleating activity. Cells were grown on TS medium at various $\mathrm{pHs}$ for $24 \mathrm{~h}$ at $18^{\circ} \mathrm{C}$. Cells were grown on TS medium ( $\mathrm{pH} \mathrm{5.0)}$ for $24 \mathrm{~h}$ at various temperatures. The measurements of the growth and activity were done as described in the Materials and Methods section. Symbols - growth ; $\mathrm{O}$, anti-nucleating activity $\left({ }^{\circ} \mathrm{C}\right)$ 
forms after culturing for 3 days in the screening medium, and the anti-nucleating activities of the supernatants were measured. Based on the results of this screening, one bacterial strain, which was isolated from the leaf surface of a camphor tree, was chosen for detailed study because it showed the highest antinucleating activity at $4^{\circ} \mathrm{C}$ of the bacterial tested. Strain $\mathrm{KINI}-1$ showed the following morphological and physiological characteristics: this isolate was Gramnegative; rods became spherical in the stationary phase growth; it was strictly aerobic and nonmotile; it produced no spores. Also strain $\mathrm{KINI}-1$ had catalase activity. The cell size of this strain was 0.9 to $1.1 \mu \mathrm{m}$ by 1.4 to $1.6 \mu \mathrm{m}$ as determined from a transmission electron micrograph. These characteristics of $\mathrm{KINI}-1$ corresponded with those of Acinetobacter calcoaceticus. Furthermore, the property of the carbon sources utilized by strain $\mathrm{KINI}-1$ corresponded to that of the phenotypic group, B2, of $A$. calcoaceticus. Based on these results, this strain with anti-nucleating activity has been named Acinetobacter calcoaceticus $\mathrm{KINI}-1$.

\section{Culture conditions and anti-nucleating activity of strain KINI-1}

The effects of $\mathrm{pH}$ during cell growth on the antinucleating activity and the growth of $\mathrm{KINI}-1$ are shown in Fig. 1 (a). The cell growth occurred over the $\mathrm{pH}$ range of 5.0 to 11.0 , and the growth was maximal at $\mathrm{pH}$ 5.0. Also, the optimum $\mathrm{pH}$ for anti-nucleating activity was 7.0. We found that strain $\mathrm{KINI}-1$ formed flocks

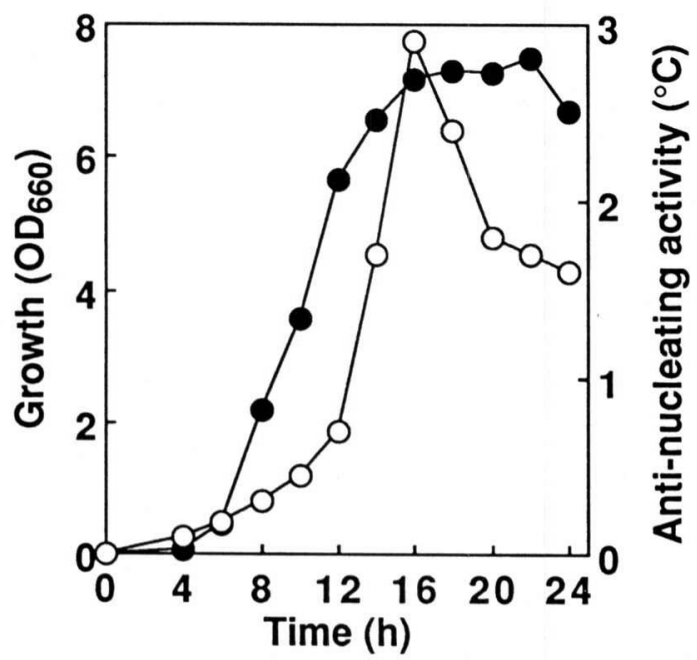

FIG. 2. The Growth curve and anti-nucleating activity of strain $\mathrm{KINI}-1$ under Optimum Conditions. Strain $\mathrm{KINI}-1$ was grown on TS medium $\left(\mathrm{pH} \mathrm{7.0)}\right.$ at $30^{\circ} \mathrm{C}$. The growth and activity were measured as described in the Materials and Methods section. Symbols : growth ; $\bigcirc$, anti-nucleating activity $\left({ }^{\circ} \mathrm{C}\right)$ by producing mucoid into the culture broth after culturing with $\mathrm{pH}$ values over 6.0. The effects of temperature during cell growth on the anti-nucleating activity and the growth of the strain are shown in Fig. 1 (b). Strain $\mathrm{KINI}-1$ has a temperature range for growth of 18 to $45^{\circ} \mathrm{C}$ and an optimum temperature of $25^{\circ} \mathrm{C}$. The anti-nucleating activity produced by this strain was maximal $\left(2.9^{\circ} \mathrm{C}\right)$ at $30^{\circ} \mathrm{C}$. This temperature range for growth corresponded to that of the type strain of $A$. calcoaceticus.

Next, we examined the relationship between the growth curve and the anti-nucleating activity (Fig. 2). Strain $\mathrm{KINI}-1$ has a generation time of $49 \mathrm{~min}$ at 30 ${ }^{\circ} \mathrm{C}$. There was first a $6 \mathrm{~h}$ lag phase, followed by an exponential growth phase. After $16 \mathrm{~h}$ of culture, the cells reached the stationary phase. The anti-nucleating activity of the culture broth was maximal at $2.7^{\circ} \mathrm{C}$ after $16 \mathrm{~h}$ of culture, which reached the stationary phase. Because strain $\mathrm{KINI}-1$ was encapsulated at the exponential growth phase, we predicted that the antinucleating activity may be due to the components of this capsule. We concluded that strain $\mathrm{KINI}-1$ must be cultured in TS medium $(\mathrm{pH} 7.0)$ at $30^{\circ} \mathrm{C}$ for $16 \mathrm{~h}$ to produce the anti-nucleating agent into the culture broth.

\section{Purification of anti-nucleating protein (ANP) from the culture broth}

The supernatant after centrifugation was subject to ultrafiltration as described in Materials and Methods. The concentrated sample (M. W. $>10,000)$ and the filtered sample (M. W. <10,000) were evaluated for the anti-nucleating activity. Also, this activity was sig-

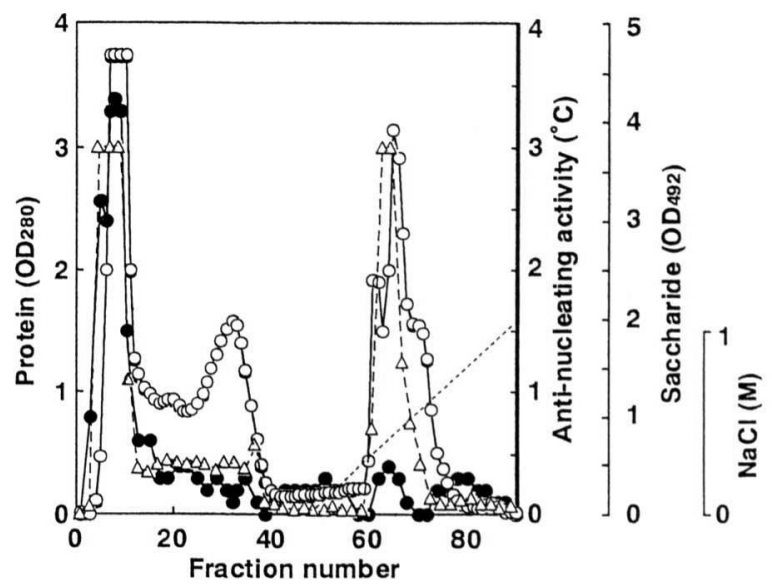

FIG. 3. QA 52 column chromatography of the anti-nucleating protein. The sample was eluted with a linear gradient of $\mathrm{NaCl}$ in $10 \mathrm{mM}$ potassium phosphate buffer $(\mathrm{pH} 7.0)$ at 4 ${ }^{\circ} \mathrm{C}$. Symbols : $\mathrm{O}$, anti-nucleating activity $\left({ }^{\circ} \mathrm{C}\right) ; 0$, absorbance at $280 \mathrm{~nm} ; \triangle$, absorbance at $492 \mathrm{~nm}$; , $\mathrm{NaCl}(\mathrm{M})$ 


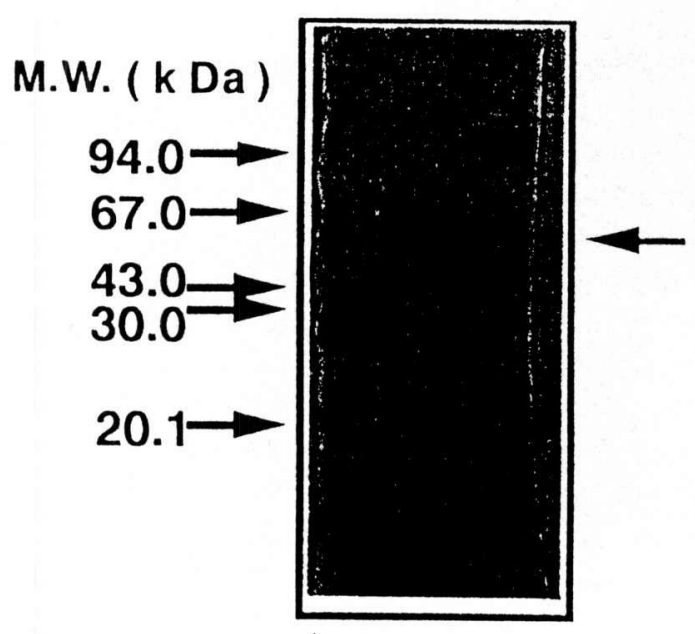

FIG.4. SDS-PAGE of the partially purified ANP from strain $\mathrm{KINI}$-1. Left lane, molecular weight marker [phosphorylase $b$ (94 kDa), bovine serum albumin (67 kDa), ovalbumin (43 $\mathrm{kDa})$, carbonic anhydrase (30 kDa), soybean trypsin inhibitor $(20.1 \mathrm{kDa})]$; Right lane, Partial Purified ANP The proteins were boiled in SDS-sample buffer (Tris/glycine) and analyzed by $12.5 \%$ SDS-PAGE. The gel was stained by the silver staining method.

nificantly suppressed by protease treatment at $30^{\circ} \mathrm{C}$ for $30 \mathrm{~min}$. This concentrated sample containing a protein with a molecular weight of 10,000 or above had a high activity $\left(2.9^{\circ} \mathrm{C}\right)$, and we proved that the anti-nucleating agent producing by strain $\mathrm{KINI}-1$ was a protein or a glycoprotein (data not shown). ANP was therefore purified from the culture broth of strain $\mathrm{KINI}-1$ after culturing under optimum conditions as described in the Materials and Methods section. As shown in Fig. 3, ANP that was eluted in the unadsorbed fraction was separated from other proteins by QA 52 column chromatography. This eluted fraction contained proteins and saccharides; therefore we considered that the ANP may be a glycoprotein that originated from the capsules. The ANP was partially purified to $90 \%$ or over by two species of gel filtration. The purified ANP preparation showed a main band on SDS-PAGE corresponding to a molecular weight of approximately $55 \mathrm{kDa}$ as shown in Fig. 4 as judged by the disappearence of the activity and the band of SDS-PAGE during protease treatment. Also, based on the results with the purified ANP using Superose 12 HR 10/10 column chromatography, ANP has a single peak and may be a monomeric protein. Furthermore, because SDS-PAGE was unstained with PAS reagent, we found that ANP was not a glycoprotein. So far, substantially all anti-nucleating proteins which had anti-nucleating activity were glycoproteins (Choy and Daniel, 1992), thus we considered that the ANP produced by strain $\mathrm{KINI}-1$ was a novel anti-freezing protein in this respect.

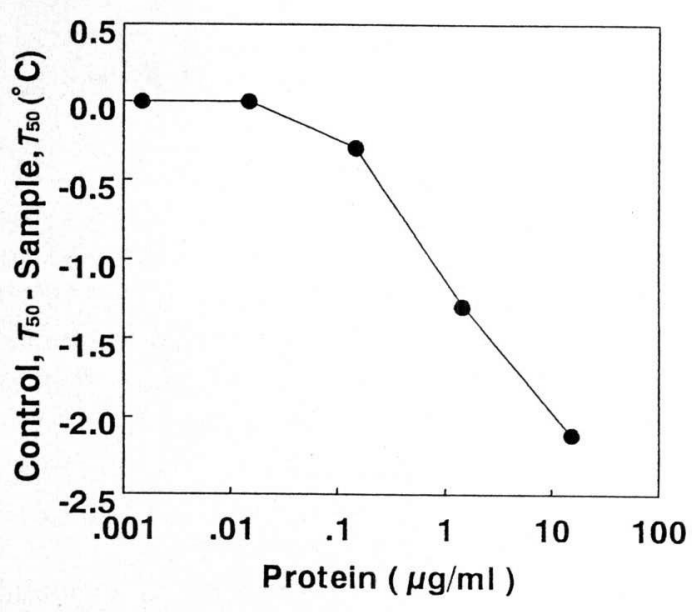

FIG.5. Effect of ANP concentration on anti-nucleating activity. Each concentration of ANP was measured for antinucleating activity by the method as described in the Materials and Methods.

\section{Characteristics of ANP from strain KINI-1}

The effect of ANP concentration on the antinucleating activity was shown in Fig. 5 . The activity increased in proportion to a concentration of $0.015 \mu \mathrm{g}$ $/ \mathrm{ml}$ or above. The purified ANP had a high activity $\left(2.2^{\circ} \mathrm{C}\right)$ compared to other anti-nucleating agents. Moreover, the anti-nucleating activity of ANP against the ice-nucleating activities of other ice-nucleating bacteria such as Pseudomonas fluorescens KUIN-1 and Xanthomonas campestris and $\mathrm{Agl}$ was examined. This result indicated that this ANP had anti-nucleating activity against these nuclei. Watanabe reported that

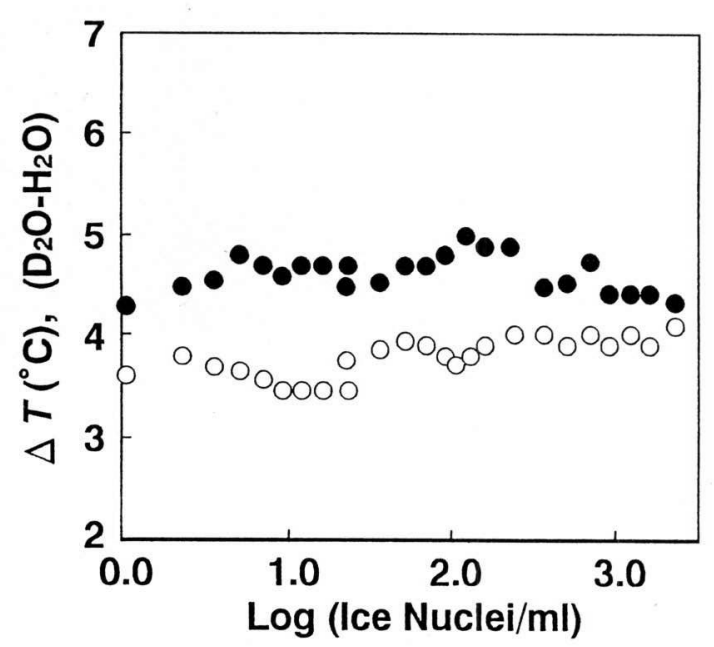

FIG.6. Freezing difference spectra in $\mathrm{D}_{2} \mathrm{O}$ and $\mathrm{H}_{2} \mathrm{O}$ regarding ice-nucleating activity in the presence of ANP. The difference spectra were calculated by the method described in the Materials and Methods. Symbols : O, Cell suspension of Erwinia uredovora KUIN-3 in the presence of ANP : $O$, Cell suspension of Erwinia uredovora KUIN-3 in the absence of ANP. 
n-octylbenzyldimethylammonium salt could protect plants from freeze-injury at a minimal concentration of 250 ppm (Watanabe et al., 1988).

The anti-nucleating mechanisms of ANP and antifreezing protein were indicated to be of two types as follows. Anti-freezing protein could prevent the growth of ice crystals by the adsorption on the ice surfaces (Choy and Daniel, 1992). In addition, anti-nucleating agents including $n$-alkylbenzyldimethylammonium salts et al. could inhibit the formation of ice nuclei by adsorption on the nuclei surface (Watanabe et al., 1988). To elucidate the anti-nucleating mechanism of ANP from strain $\mathrm{KINI}-1$, the effect of a proteinmodifying reagent such as $\mathrm{N}$-bromosuccinimide, $\mathrm{N}$ ethylmaleimide and succinic anhydride on the antinucleating activity was examined. The anti-nucleating activity was not substantially affected by the addition of protein-modifying reagents (data not shown). Based on this result, we assumed that the binding of ANP to the ice nuclei was not through chemical linkage but physical linkage. Next, the hydrophobicities of the ice nucleus surface before or after binding to ANP were examined using the freezing difference spectra in $\mathrm{D}_{2} \mathrm{O}$ versus $\mathrm{H}_{2} \mathrm{O}$. As shown in Fig. 6 , the ice nucleus in the presence of ANP had higher hydrophobicity than that in the absence of ANP. This result indicated that ANP strongly bound to the surface of the ice nucleus and that ANP may be a hydrophobic protein based on the band condition of SDS-PAGE as shown in Fig. 4. In addition, to determine how ANP affected the surface charge of the ice nuclei, this charge was

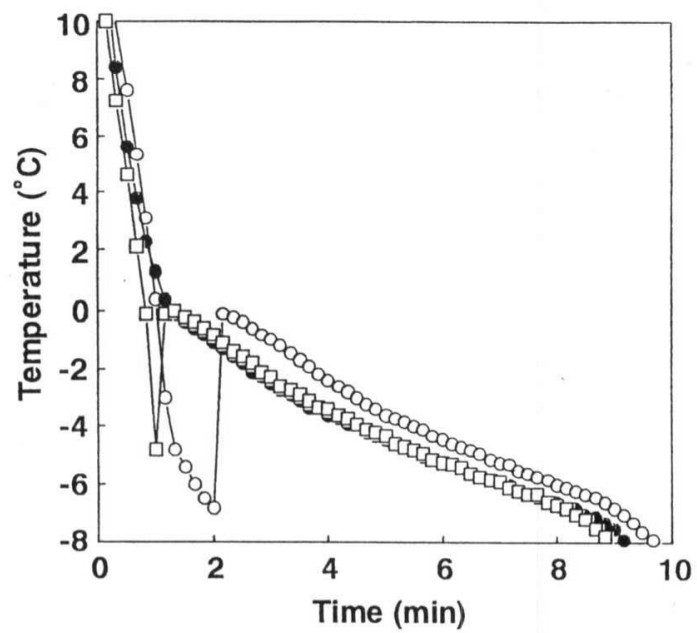

FIG. 7. Effect of ANP on the freezing curve of cell suspension from Erwinia uredovora KUIN-3. The measurements of freezing spectra were done as described in the Materials and Methods. Symbols : Cell suspension (OD, 0.1) of Erwinia uredovora KUIN-3; $0,50 \mathrm{mM}$ potassium phosphate buffer ( $\mathrm{pH} 7.0) ; \square$, Cell suspension in the presence of ANP. measured using a fluorescence reagent. We found that the surface charge of ice nuclei on the cell membrane was changed from 6.6 to 6.1 by the addition of ANP. Franks reported that the determining factors for the formation of ice nuclei by materials included the following three conditions : similarity to the crystal lattice, the paucity of the surface charge, and the high hydrophobicity of the ice nuclei (Franks, 1985). On the basis of these factors, we predicted that the elevated hydrophobicity after binding of ANP was independent of the anti-nucleating activity of ANP. From these results, we could predict that the anti-nucleating activity of this ANP was introduced by the changes in the structure and charge of the ice nuclei. Furthermore, a comparison of the freezing spectra as shown in Fig. 7 introduced the concept of the antinucleating mechanism of the ANP from strain $\mathrm{KINI}-1$. The mixture solution in the presence of ANP caused a supercooling condition at $-5.0^{\circ} \mathrm{C}$ in the cell suspension of Erwinia uredovora KUIN-3. This phenomenon demonstrated that this ANP has anti-nucleating activity by inhibiting the formation of ice nuclei in the same manner as EMG-8 and EMG-12 (Arai and Watanabe, 1985). The anti-freezing proteins, rather than binding uniformly to all ice surfaces, adsorb preferentially on specific planes of the ice crystals (Choy and Daniel, 1992). As a result, they deter the formation of the ice; thus we predicted that ANP deters the formation of ice nucleus in a manner like that of anti-freezing proteins.

In this study, we isolated an anti-nucleating proteinproducing bacterium, Acinetobacter calcoaceticus $\mathrm{KINI}-1$, from the leaf of a camphor tree. The major idea addressed in this study is the finding of an antinucleating protein from bacteria. This isolate could produce ANP with high anti-nucleating activity against the ice nuclei arising from various bacteria or Agl. Also, we found that this activity was caused by ANP binding to ice nuclei in the way that anti-freezing proteins do. To the best of our knowledge this is the first report of a protein, produced by bacteria, that has an anti-nucleating activity. Further work is in progress to examine the structure of the ANP in more detail as well as its anti-nucleating mechanism.

\section{REFERENCES}

Arai, S., and Watanabe, M (1985) The protein that prevent the formation of ice crystal. (in Japanese), Kagaku To Seibutsu, 23, 363-373.

Choy, L. HEW, and Daniel, S. C. Y. (1992) Protein interaction with ice. Eur. J. Biochem., 203, 33-42.

Franks, F. (1985) Biophysics and Biochemistry at Low Temperature (in Japanese), pp.36-37, Japan UNL Agency Inc., Tokyo. 
Kawahara, H., Mano, Y., Hamada, R., and Obata, H. (1994) Role of spermidine in the ice-nucleating activity of the EIM from Erwinia uredovora KUIN-3. Biosci. Biotech. Biochem., 58, 2201-2206.

Kawahara, H., and Obata, H. (1996) Identification of a compound in spices inhibiting the ice-nucleating activity of Erwinia uredovora KUIN-3. J. Antibact. Antifung. Agents, 24, 95-100.

Kin, H. K., Orser, C., Lindow, S.E., and Sands, D. C. (1987) Xanthomonas campestris pv. translucens strains active in ice nucleation. Plant Dis., 71, 994997.

Laemmli, U. K. (1970) Cleavage of structural proteins during the assembly of the head of bacteriophage T4. Nature (London), 227, 680-685.

Lindow, S. E., Arny, D. C., and Upper, C. D. (1982) The relationship between ice nucleation frequency of bacteria and frost injury. Plant Physiol., 70, 10901093.

Lindow, S. E., Arny, D. C., and Upper, C. D. (1983) Biological control of frost injury I: An isolate of Erwinia herbicola antagonistic to ice nucleation active bacteria. Phytopathology., 73, 1097-1102.

Lindow, S. E. (1988) Lack of correlation of in vitro antibiosis with antagonism of ice nucleation active bacteria on leaf surfaces by non-ice nucleation active bacteria. Phytopathology, 78, 444-450.

Lowry, O. H., Rosebrough, N. J., Farr, A. L., and Randall, R. J. (1951) Protein measurement with the Folin phenol reagent. J. Biol. Chem., 193, 265275.

Maki, L. R., Galyan, E. L., Chang-Chein, M., and Caldwell, D. R. (1974) Ice nucleation induced by Pseudomonas syringae. Appl. Microbiol., 28, 456459.

Obata, H., Saeki, Y., Tanishita, J., Tokuyama, T., Hori, H., and Higashi, Y. (1987) Identification of an ice nucleating bacterium $\mathrm{KUIN}-1$ as Pseudomonas fluorescens and its ice nucleation properties. Agric. Biol. Chem., 51, 1761-1766.

Obata, H., Hayashi, K., Tanishita, J., Hasegawa, Y., and Tokuyama, T. (1987) Inactivation of the icenucleating activity of Pseudomonas fluorescens KUIN-1 by smoke condensate and related substance. J. Antibact. Antifung. Agents, 15, 593-599.

Obata, H., Nakai, T., Tanishita, J., and Tokuyama, T. (1989) Identification of an ice-nucleating bacterium and its ice-nucleation properties. J. Ferment. Bioeng., 67, 143-147.

Obata, H., Takinami, K., Tanishita, J., Hasegawa, Y., Kawate, S., Tokuyama, T., and Ueno, T. (1990) Identification of a new ice nucleating bacterium and its ice nucleation properties. Agric. Biol. Chem., 54, 725-730.

Obata, H., Okada, M., Kawahara, H., and' Tokuyama, T. (1992) Inactivation of ice-nucleating activity of Pseudomonas fluorescens $\mathrm{KUIN}-1$ by glucosealkaline degradation products and copper ion system. J. Antibact. Antifung. Agents, 20, 235-240.

Ozawa, Y. (1977) Handbook of Agricultural Meteorology (in Japanese), pp.520-528, Yokendo, Tokyo.

Turner, M. A., Arellano, F., and Kozloff, L. M. (1990) Three separate classes of bacterial ice nucleation structure. J. Bacteriol., 172, 2521-2526.

Vali, G. (1971) Quantitative evaluation of experimental results on the hetero-genous freezing nucleation of supercooled liquids. J. Atmos. Sci., 28, 402-409.

Watanabe, M., Makino, T., Okada, K., Hara, M., Watabe, S., and Arai, S. (1988) Alkylbenzyldimethylammonium salts as inhibitors for the ice nucleating activity of Erwinia ananašs. Agric. Biol. Chem., 52 , 201-206.

Wilson, M., and Lindow, S. E. (1994) Ecological similarity and coexistence of ephiphytic ice-nucleating $\left(\mathrm{ICe}^{+}\right)$Pseudomonas syringae strains and a nonice-nucleating (lce ${ }^{-}$) biological control agent. Appl. Environ. Microbiol., 60, 3128-3137.

Yakofsky, S. A., Levin, Z., and Moshe, A. (1981) Some basic characteristics of bacterial freezing nuclei. J. Appl. Meteorol., 20, 1013-1019. 